M.I. Boyko, A.V. Makogon, A.I. Marynin

\title{
ENERGY EFFICIENCY OF THE DISINFECTION TREATMENT OF LIQUID FOODSTUFFS BY HIGH-VOLTAGE PULSE EFFECTS
}

Purpose. Experimentally determine the rational modes and energy efficiency of decontamination treatment of flowing food products using high-voltage impulse actions in comparison with traditional pasteurization. Methodology. We used pulse generation method with the help of a step-up transformer, high-voltage pulse capacitors and spark gaps with a system of peaking of pulse front to obtain high-voltage pulses in working chambers - the generator load. The pulses on the load were measured by a low-resistance resistive voltage divider, were transmitted over a broadband coaxial cable and recorded using an analog C8-12 oscilloscope or a Rigol DS1102E digital oscilloscope with a bandwidth of $100 \mathrm{MHz}$ for each. The working chambers were filled with water, milk or milk whey and consisted of an annular hull made of PTFE and metal electrodes forming the bottom and the chamber cover having flat linings of food grade stainless steel for contact with the food product inside the chamber. Results. We obtained high-voltage pulses on the generator load with a base duration of 300 to 1200 ns at pulse repetition rates up to 500 pulses per second. We obtained experimentally the amplitude of the voltage pulses on the generator load up to $75 \mathrm{kV}$, and the electric field strength up to $35 \mathrm{kV} / \mathrm{cm}$ in working chambers with a gap of $22 \mathrm{~mm}$ and up to $50 \mathrm{kV} / \mathrm{cm}$ in working chambers with a gap of $15 \mathrm{~mm}$. These characteristics of the pulses allowed complete and irreversible inactivation of microorganisms in food liquids in working chambers. Originality. We showed that there are modes of treatment food products with the help of highvoltage pulse actions, which allow better to preserve the biological and nutritional value of the products in comparison with heat treatment with their complete disinfection and at a significantly lower specific energy consumption. Practical value. The experimental regimes for treating milk, whey and water with reduced specific energy consumption open the prospect of industrial application of a complex of high-voltage pulse actions for the disinfecting treatment of water-containing food products. References 7, tables 3, figures 10.

Key words: generator of high-voltage pulses, transformer, capacitor, multi-gap discharger, multichannel switch, working chamber, disinfecting food treatment.

Цель. Экспериментально определить рациональные режимы и энергоэффективность обеззараживающей обработки текучих пищевых продуктов при помощи высоковольтных импульсных воздействий в сравнении с традиционной пастеризацией. Методика. Для получения высоковольтных импульсов на рабочих камерах нагрузке генератора применена методика генерирования импульсов при помощи повыщающего трансформатора, высоковольтных импульсных конденсаторов и разрядников с системой обострения фронта импульсов. Импульсы на нагрузке измерялись при помощи низкоомного резистивного делителя напряжения, передавались по широкополосному коаксиальному кабелю и регистрировались при помощц аналогового осциллографа С8-12 или цифрового осциллографа Rigol DS1102E с полосой пропускания 100 МГи у каждого. Рабочие камеры заполнялись водой, молоком или молочной сывороткой и состояли из кольцеобразного корпуса, выполненного из фторопласта, и металлических электродов, образующих дно и крышку камеры, имеющих плоские накладки из пицевой нержавеющей стали для контакта с пищевым продуктом внутри камеры. Результаты. Получены высоковольтные импульсы на нагрузке генератора с длительностью по основанию 300-1200 нс при частотах следования импульсов до 500 имп/с. Экспериментально полученные амплитуды импульсов напряжения на нагрузке генератора - до 75 кВ, а напряженности электрического поля - до 35 кВ/см в рабочих камерах с зазором 22 мм и до 50 кВ/см в рабочих камерах с зазором 15 мм. Указанные характеристики импульсов позволили осуществить полную и необратимую инактивацию микроорганизмов в пищевых жидкостях в рабочих камерах. Научная новизна. Показано, что существуют режимы обработки пищевых продуктов при помощи высоковольтных импульсных воздействий, позволяющие лучще сохранить биологическую и пищевую ценность продуктов по сравнению с тепловой обработкой при их полном обеззаражсиании и при существенно меньщих удельных энергозатратах. Практическая значимость. Полученные экспериментально режимы обработки молока, молочной сыворотки и воды с уменьшенными удельными энергозатратами открывают перспективу промышленного применения комплекса высоковольтных импульсных воздействий для обеззараживающей обработки водосодержащих пищевых продуктов. Библ. 7, табл. 3, рис. 10.

Ключевые слова: генератор высоковольтных импульсов, трансформатор, конденсатор, многозазорный разрядник, многоканальный разрядник, рабочая камера, обеззараживающая обработка пищевых продуктов.

Introduction. Traditional thermal methods of liquid food products are water-containing. Therefore, the disinfecting treatment (pasteurization and thermal important question is also about rational modes of sterilization) of liquid food products, wine materials, decontaminating water treatment by using CHVIA.

beverages are energy-consuming and do not allow to The goal of the work is to experimentally determine preserve their initial biological and nutritional value to a the rational modes and energy efficiency of sufficient extent $[1,2]$. One of the most promising ways of decontaminating treatment of liquid food products by non-thermal disinfection treatment of products is the way means of high-voltage impulse actions in comparison with of processing by means of a complex of high-voltage traditional pasteurization.

impulse actions (CHVIA). The English-language scientific Experimental installation. To carry out literature uses the term PEF-treatment (PEF - pulsed experimental studies, we used a facility, which was first electric field, treatment with a pulsed electric field). Most 
described in [3]. The electrical circuit of the installation with the control system is shown in Fig. 1.

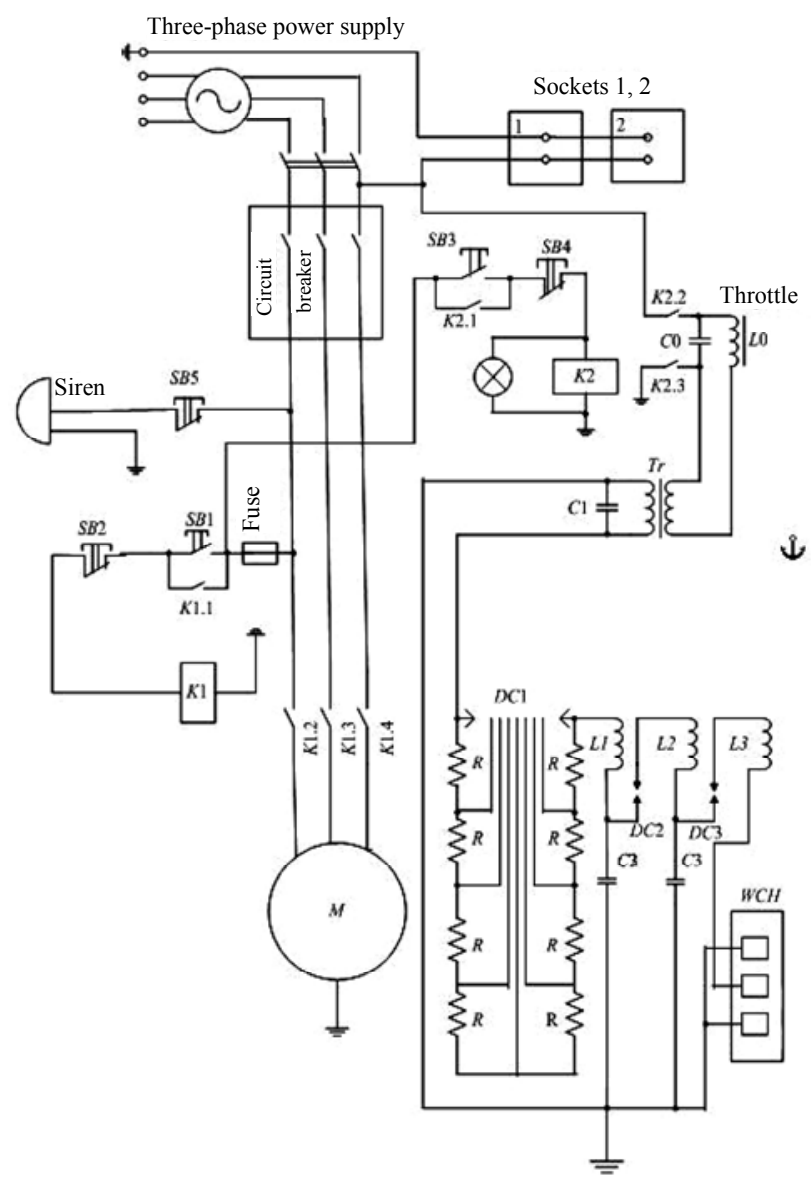

Fig. 1. Electrical circuit of the CHVIA installation with a control system

The installation consists of low-voltage and highvoltage parts. The high-voltage part consists of a generator of high-voltage pulses and a load - a working chamber $W C H$. The generator contains a start cascade $(C 1, D C 1)$ and two cascades of sharpening $(C 2, D C 2$ and $C 3, D C 3)$. Each cascade contains a capacitor and an discharger. The discharger $D C 1$ of the start cascade is multi-gap. All arresters are multi-channel. In the simplest mode of operation, only the first cascade is used. The disadvantage of this mode is the insufficient steepness of the pulse front on the load - the $\mathrm{WCH}$ working chamber. Therefore, the main amount of the experiments was carried out using all three cascades.

After connecting to a three-phase power supply, during flow processing, pressing the button $S B 1$ starts the pump electric motor $M$ which pumps the processed product through the $\mathrm{WCH}$ working chamber. Pressing the button $S B 3$ energizes the relay $K 2$, its contacts $K 2.1, K 2.2$, $K 2.3$ are closed, and the phase voltage of the power network through the filter $L O-C O$ is fed to the primary (low-voltage) winding of the transformer $\operatorname{Tr}$ starting the installation. As a result, on the load - the $W C H$ working chamber, pulses are formed of high voltage (up to $120 \mathrm{kV}$ ) and current of both polarities with repetition frequency up to 500 pulses. The button $S B 4$ switches off the supply of voltage to the filter $L 0-C 0$ and to the primary winding of the transformer $\operatorname{Tr}$. By pressing the button $S B 2$, the pump electric motor $M$ is switched off.

Working chambers. The working chambers (WCH) which are the load for the CHVIA installation are divided into stationary and flowing. In stationary chambers, portions of the product are replaced manually, and in flow chambers through the flow through the chamber which provides the pump and a pumping system. The latter contains containers for feeding and receiving the treated liquid product and hoses. It is in the $\mathrm{WCH}$ that energy is released which is initially stored in the main high-voltage capacitor of the installation.

Typical stationary and flow chambers are shown in Fig. 2 and Fig. 3, respectively.

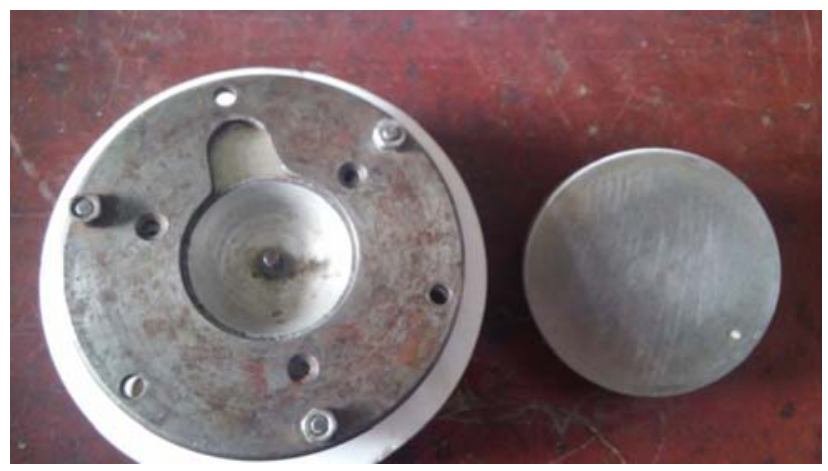

Fig. 2. Variant of stationary WCH with cover - electrode located near

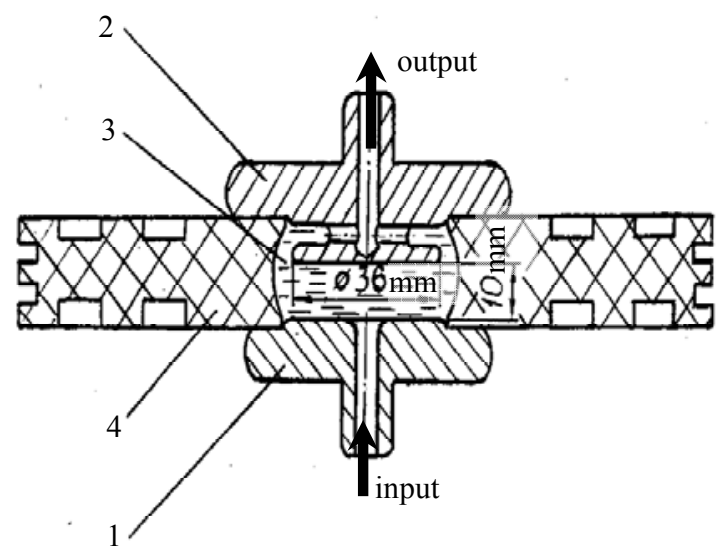

$a$

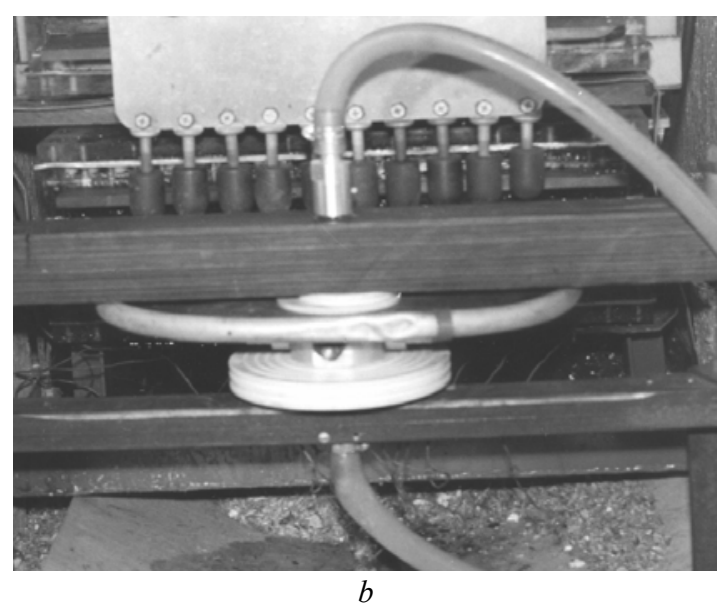

Fig. 3. $a$ - variant of the design of the flowing technological WCH: 1, 2 - electrodes, 3 - internal volume of the chamber, 4 - dielectric housing; $b-\mathrm{WCH}$ 
Experimental studies of CHVIA methods for the coefficient $k_{d}=1000$ was used. As the recording device an treatment (PEF-treatment) of food products and water analog storage oscilloscope C8-12 with a bandwidth of treatment. We experimentally investigated the effect of $100 \mathrm{MHz}$ and a digital oscilloscope RIGOL DS1102E with CHVIA treatment on microbiological contamination, a bandwidth of $100 \mathrm{MHz}$ were used.

sanitary and hygienic properties and organoleptic parameters of milk, milk whey and water. The investigations were carried out in different treatment
modes in stationary and flowing WCHs at the CHVIA installation described above.

A photo of an operating CHVIA installation during the experiments is shown in Fig. 4. The product to be processed was poured into a $\mathrm{WCH}$ which was previously sterilized with an alcohol burner, and the chamber was closed with a sterilized lid. Two types of cameras were used: with an interelectrode gap (the distance between the disk cover of the chamber and its bottom) of $15 \mathrm{~mm}$ and with an interelectrode gap of $22 \mathrm{~mm}$. We varied the treatment time from $10 \mathrm{~s}$ to $30 \mathrm{~s}$. Fig. 5 shows a WCH with an interelectrode gap of $22 \mathrm{~mm}$.

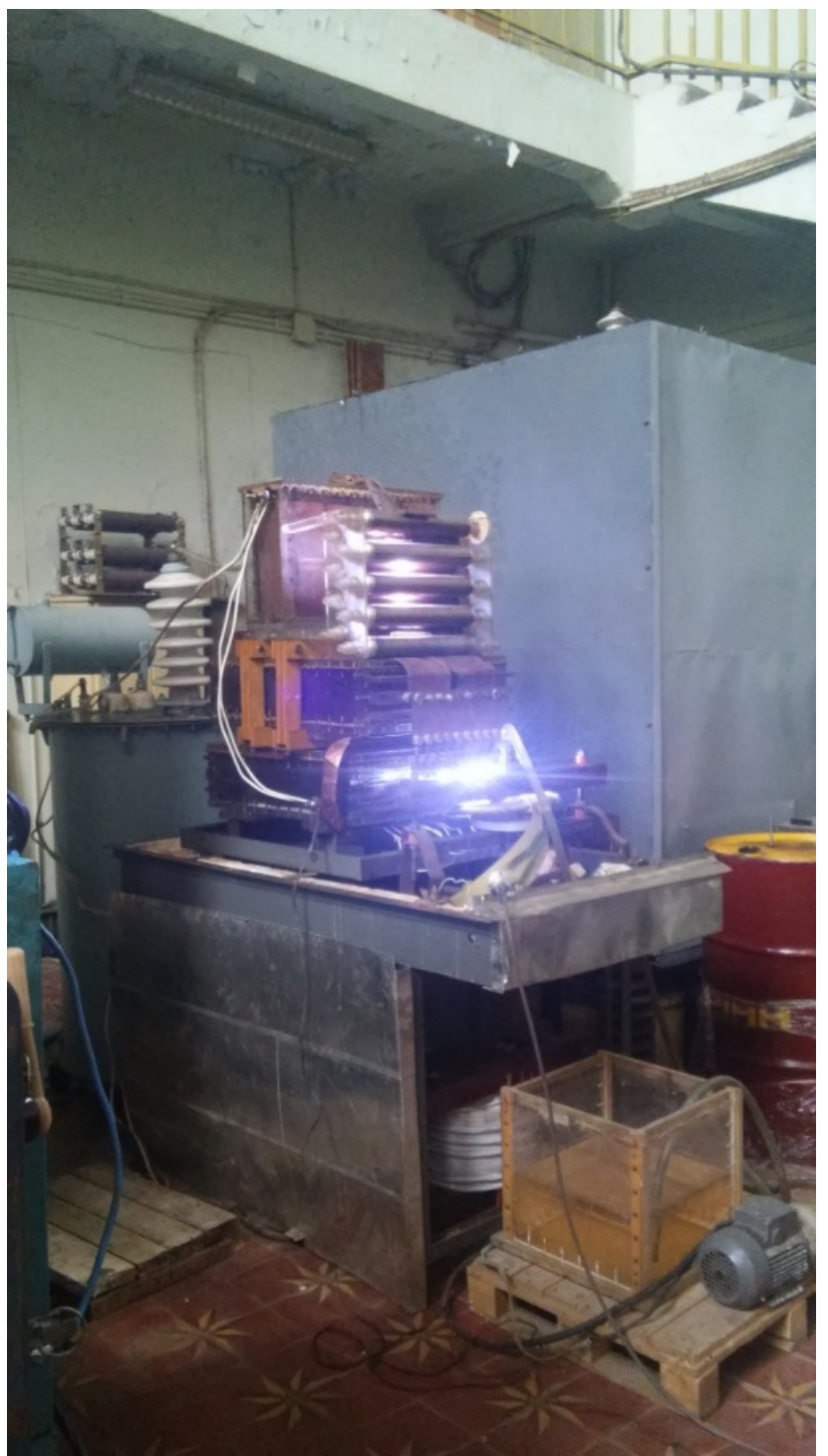

Fig. 4. Photo of operating CHVIA installation

To measure the characteristics of pulses on the load of the CHVIA installation - the working chamber, a resistive low-resistance voltage divider with a division
To protect against electromagnetic interference, the oscilloscope was located in a shielding cabin with a door screened circuit along the contour. The signal from the low-voltage arm of the voltage divider to the oscilloscope in the measuring cabinet was fed using a coaxial cable with a double braid. The door in the measuring cabinet can be opened and closed tightly both from the outside and from the inside.

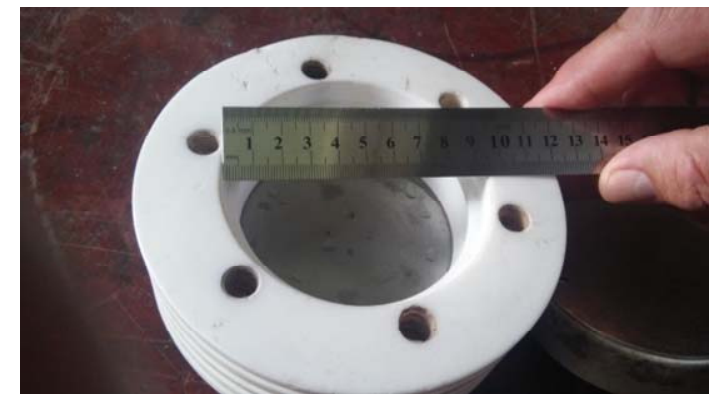

$a$

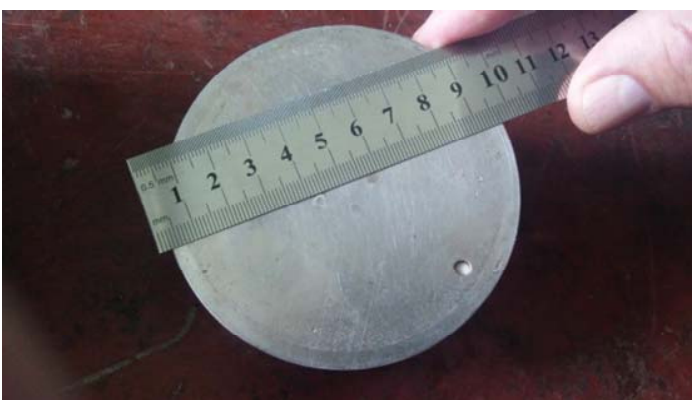

$b$
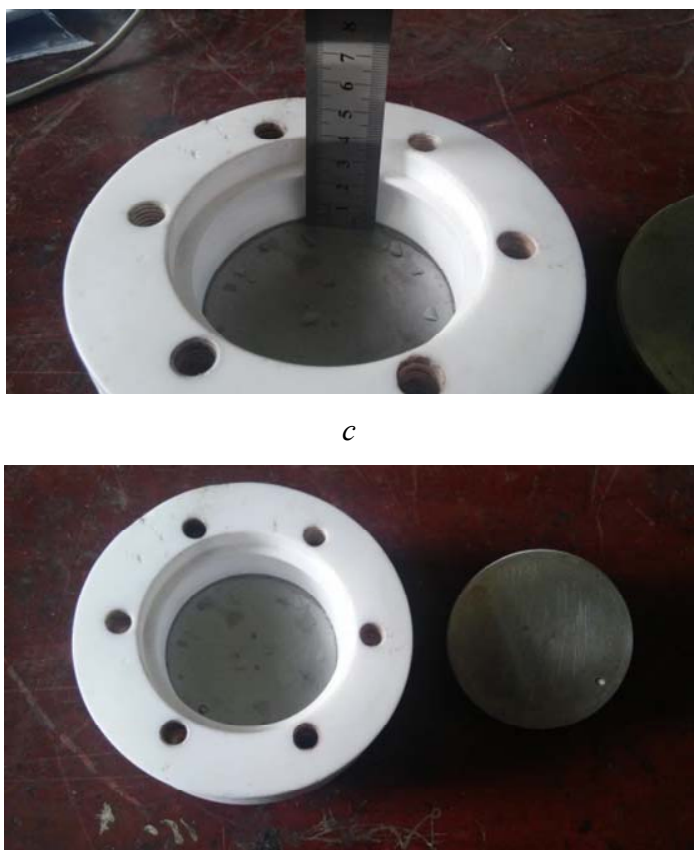

$d$

Fig. 5. Working chamber with an interelectrode gap of $22 \mathrm{~mm}$ : $a$-body made of fluoroplastic, $b$ - cover, $c$ - interelectrode gap of $22 \mathrm{~mm}, d$ - cover near the chamber 
The inactivating effect of CHVIA on various milk products (milk, whey, yogurt), as well as water, was investigated. To do this, our colleagues, co-executors from the National University of Food Technologies (NUFT), the city of Kiev, prepared water for experiments. They took water «Sofia Kiev» and infested it with bacteria of the E-coli group. At each treatment mode of all the fluids studied, three repetitions were performed.

The values of the interelectrode gap in the spark dischargers had the following values: for a multi-gap discharger (MGD), the value of an individual gap is approximately $5 \mathrm{~mm}$, for the first sharpening discharger approximately $20 \mathrm{~mm}$, for a second sharpening discharger approximately $20 \mathrm{~mm}$. At the same time, the number of gaps involved in the MGD was from 4 to 7 inclusive.

The treatment of samples of liquid products and water in the $\mathrm{WCH}$ in all modes was carried out by pulses of both polarities. During the period of $20 \mathrm{~ms}$ of the AC network voltage during the half-period of the positive voltage of $10 \mathrm{~ms}$, approximately 4 pulses of the same polarity were applied to the $\mathrm{WCH}$, and about 4 pulses of a different polarity were applied to the $\mathrm{WCH}$ during the half-period of the negative voltage of $10 \mathrm{~ms}$.

Results of experimental studies of the methods of CHVIA treatment (PEF-treatment). Fig. 6 shows an oscillogram of pulses on the WCH with milk at 7 ruptured gaps of 8 in a multi-gap discharger - MGD without the influence of electromagnetic interference and with a clearly visible pulse front.

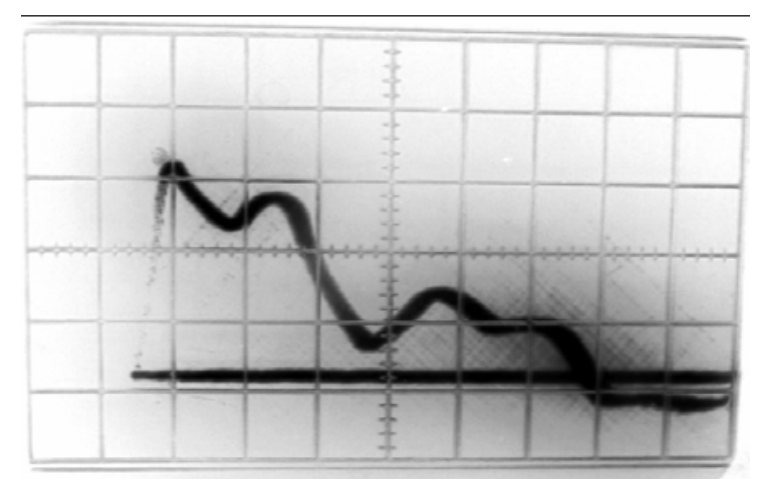

Fig. 6. Typical oscillogram of the voltage pulse on the $\mathrm{WCH}$ with raw milk. The scale division along the time axis is $50 \mathrm{~ns} / \mathrm{div}$; along the axis of the process is $20 \mathrm{kV} / \mathrm{div}$. In multi-gap discharger 7 gaps of 8 are ruptured. The gap in the WCH is $d=22 \mathrm{~mm}$

It follows from the oscillogram that the pulse front duration in milk is about $20 \mathrm{~ns}$ and the pulse duration along the base before passing through zero is about $300 \mathrm{~ns}$. Amplitude of the voltage pulse is not less than $60 \mathrm{kV}$. From this it follows that the amplitude of the electric field strength in milk is $60 / 2.2 \approx 27.3 \mathrm{kV} / \mathrm{cm}$. It is also important that in milk which has a resistivity less than tap water or table water, the pulse shape is slightly oscillatory.

Fig. 7 shows a typical oscillogram of the pulse voltage on the WCH with water, contaminated with E-coli. The oscillogram was obtained using a digital oscilloscope Rigol 1102 E.

From the oscillogram in Fig. 7 it follows that the amplitude of the voltage on the WCH with water in this mode is not less than $72 \mathrm{kV}$, the pulse duration on the base is approximately $1200 \mathrm{~ns}$, and the pulse shape is aperiodic, unipolar, does not pass through the zero line. The zero line is shown in Fig. 7 and further by the arrow located to the left of the oscillogram.

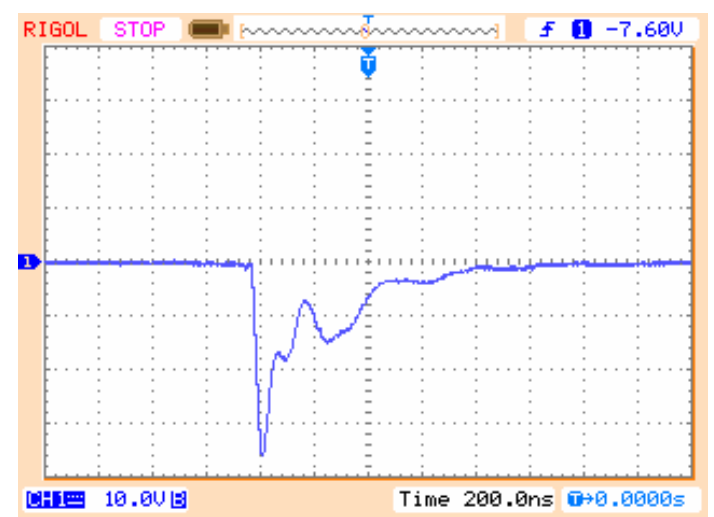

Fig. 7. Typical oscillogram of the voltage pulse on a working chamber with water «Sofia Kiev» seeded by E-coli. The scale division along the time axis is $200 \mathrm{~ns} / \mathrm{div}$; along the axis of the process is $20 \mathrm{kV} / \mathrm{div}$. In the multi-gap discharger 6 gaps of 8 are ruptured. The gap in the $\mathrm{WCH}$ is $d=22 \mathrm{~mm}$. A low-resistance resistive voltage divider with division coefficient $k_{d} \approx 2000$ is used

Two additional bursts at the fall of the pulse on this oscillogram, as well as on other oscillograms, are due to the presence of three high-voltage capacitive storage devices: the main one and two sharpening ones. The front part of the pulse is due to the last (second) sharpening cascade with the second sharpening capacitive storage, the first additional burst at the pulse decay is due to the presence of the first cascade of sharpening with the first sharpening capacitive storage, and the second additional surge at the pulse decay is due to the presence of the main high-voltage capacitive storage device.

The results of microbiological analyzes of water are given in Table 1.

Table 1

Detection of the bacteria of the family E.coli in water

\begin{tabular}{|c|c|c|c|c|}
\hline \begin{tabular}{|l|} 
The name \\
of the \\
indicator \\
(units of \\
measure \\
CFU $/ \mathrm{cm}^{3}$ )
\end{tabular} & $\begin{array}{c}\text { Results of } \\
\text { investigations, } \\
\mathrm{CFU} / \mathrm{cm}^{3}\end{array}$ & $\begin{array}{c}\text { Approximated } \\
\text { treatment } \\
\text { mode } \\
(E, \mathrm{kV} / \mathrm{cm})\end{array}$ & $\begin{array}{c}\text { Calculated } \\
\text { treatment } \\
\text { mode, } \\
(E, \\
\mathrm{kV} / \mathrm{cm})\end{array}$ & $\begin{array}{c}\text { Treatment } \\
\text { duration } \\
(t, \mathrm{~s})\end{array}$ \\
\hline $\begin{array}{l}\text { Water } \\
\text { sterile. } \\
\text { Dilution } \\
\text { E.coli } 10^{6}\end{array}$ & 210 & 30 & 20.09 & 10 \\
\hline $\begin{array}{l}\text { Water } \\
\text { sterile. } \\
\text { Dilution } \\
\text { E.coli } 10^{6}\end{array}$ & 0 & 30 & 31.8 & 20 \\
\hline \begin{tabular}{|l|} 
Water \\
sterile. \\
Dilution \\
E.coli $10^{8}$
\end{tabular} & 60 & 30 & 19.0 & 10 \\
\hline \begin{tabular}{|l|} 
Water \\
sterile. \\
Dilution \\
E.coli $10^{8}$
\end{tabular} & 0 & 30 & 1.8 & 20 \\
\hline
\end{tabular}


Fig. 8 shows a typical oscillogram of pulse voltage on the WCH with milk whey.

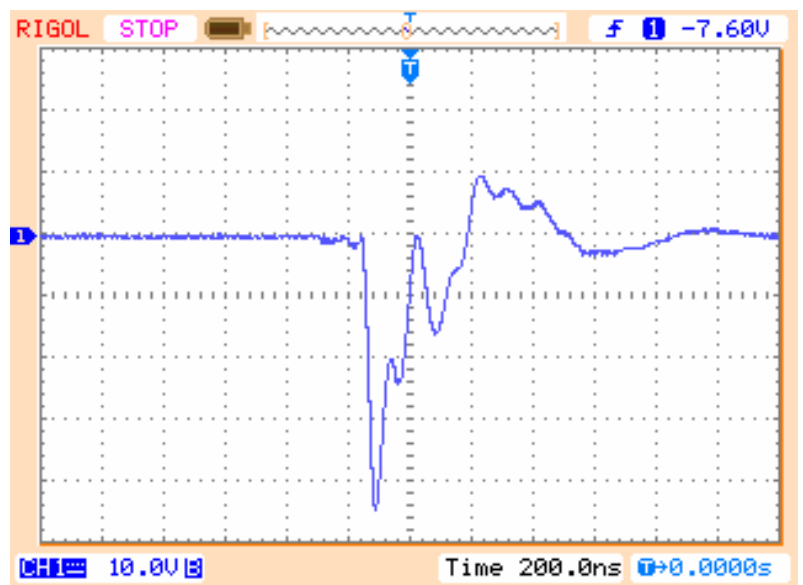

Fig. 8. Typical oscillogram of the voltage pulse on a working chamber with milk whey. The scale division along the time axis is $200 \mathrm{~ns} / \mathrm{div}$; along the axis of the process is $10 \mathrm{kV} / \mathrm{div}$. In the multi-gap discharger 6 gaps of 8 are ruptured. The gap in the WCH is $d=22 \mathrm{~mm}$. A low-resistance resistive voltage divider with division coefficient $k_{d} \approx 1000$ is used

The pulse duration along the base on the oscillogram (Fig. 8) is approximately 350 ns. The pulse shape is oscillatory with a large decrement of oscillations. The amplitude of the voltage pulse on this oscillogram is approximately $45 \mathrm{kV}$, and the amplitude of the voltage is approximately $20.45 \mathrm{kV} / \mathrm{cm}$.

In Fig. 9 shows a typical oscillogram of the pulse voltage on the WCH with raw milk.

The results of microbiological analyzes of milk whey treated with CHVIA pulses, a sample oscillogram of which is presented in Fig. 8, are given in Table 2-5.

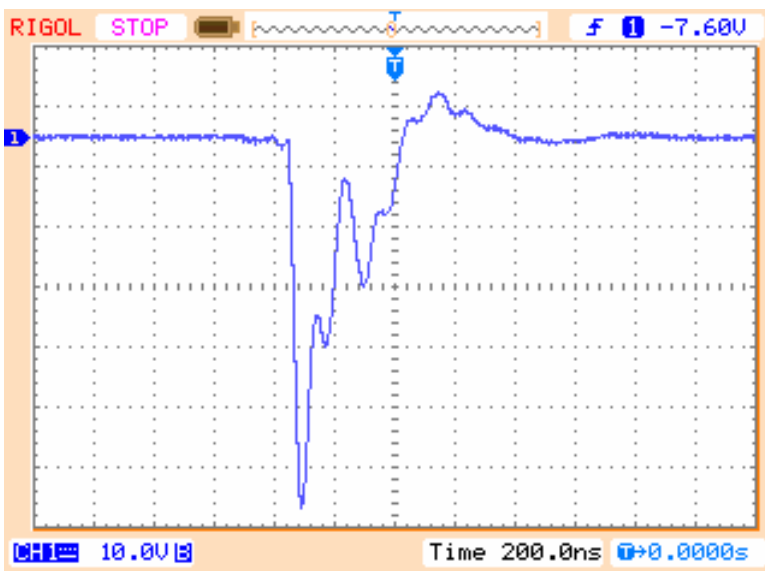

Fig. 9. Typical oscillogram of the voltage pulse on a working chamber with raw milk. The scale division along the time axis is $200 \mathrm{~ns} / \mathrm{div}$; along the axis of the process is $10 \mathrm{kV} / \mathrm{div}$. In the multi-gap discharger 6 gaps of 8 are ruptured. The gap in the $\mathrm{WCH}$ is $d=22 \mathrm{~mm}$. A low-resistance resistive voltage divider with division coefficient $k_{d} \approx 1000$ is used

Table 2

The results of the analyzes on the detection of E.coli family bacteria in milk whey after CHVIA treatment

\begin{tabular}{|l|c|}
\hline $\begin{array}{l}\text { The name of the indicator, units of measure } \\
C F U / \mathrm{cm}^{3} E . \text { coli }\end{array}$ & $\begin{array}{c}\text { Result, } \\
\mathrm{CFU} / \mathrm{cm}^{3}\end{array}$ \\
\hline $\begin{array}{l}\text { at } E \approx 30 \mathrm{kV} / \mathrm{cm}, \text { total treatment duration } \\
t=10 \mathrm{~s} \text { and dilution } 10^{6}\end{array}$ & 30 \\
\hline $\begin{array}{l}\text { at } E \approx 30 \mathrm{kV} / \mathrm{cm}, \text { total treatment duration } \\
t=20 \mathrm{~s} \text { and dilution } 10^{6}\end{array}$ & 0 \\
\hline $\begin{array}{l}\text { at } E \approx 30 \mathrm{kV} / \mathrm{cm}, \text { total treatment duration } \\
t=10 \mathrm{~s} \text { and dilution } 10^{8}\end{array}$ & 20 \\
\hline $\begin{array}{l}\text { at } E \approx 30 \mathrm{kV} / \mathrm{cm}, \text { total treatment duration } \\
t=20 \mathrm{~s} \text { and dilution } 10^{8}\end{array}$ & 0 \\
\hline
\end{tabular}

Physicochemical parameters of initially raw milk after CHVIA treatment

\begin{tabular}{|l|c|c|c|c|}
\hline $\begin{array}{c}\text { The name of the } \\
\text { indicator, units of } \\
\text { measure }\end{array}$ & ND for testing techniques & Investigation result & $\begin{array}{c}\text { Indicator value in } \\
\text { accordance with ND }\end{array}$ & Compliance with ND \\
\hline 1 & 2 & 3 & 4 & 5 \\
\hline \multicolumn{4}{|c|}{ Determination of the mass portion of vitamin C by titrimetric method in food products } \\
\hline $\begin{array}{l}\text { mass part of vitamin C, } \\
\text { ppm }\end{array}$ & GOST 30627.2-98 & 5.0 & not regulated & corresponds to ND \\
\hline \multicolumn{5}{|c|}{ Determination of peroxidase by the method of qualitative analysis in food products } \\
\hline $\begin{array}{l}\text { peroxidase for baked, } \\
\text { ultra-pasteurized, } \\
\text { sterilized milk }\end{array}$ & DSTU 7380:2013 & detected & absent & does not correspond \\
\hline $\begin{array}{l}\text { Dhosphatase for } \\
\text { pasteurized milk }\end{array}$ & \multicolumn{1}{|c|}{ DSTU 7380:2013 } & not detected & absent & corresponds \\
\hline
\end{tabular}

From Table 2 it follows that after complete treatment of milk whey in the WCH during $20 \mathrm{~s}$ by high-voltage pulses (see Fig. 8) complete inactivation of E.coli bacteria is guaranteed. When treated during $10 \mathrm{~s}$ from 20 to 30 colony forming units remain not inactivated. Thus, the existence of a mode of complete guaranteed inactivation at CHVIA treatment of products was confirmed experimentally. In control (not treated by CHVIA) samples of milk whey, a continuous growth of E.coli bacteria $\left(>>1000 \mathrm{CFU} / \mathrm{cm}^{3}\right)$ was observed.
The pulse duration along the base on the oscillogram in Fig. 9 is approximately 350 ns. The pulse shape is oscillatory with a large decrement of oscillations (weakly vibrational). The amplitude of the voltage pulse on this oscillogram is approximately $60 \mathrm{kV}$, and the amplitude of the electric field strength is approximately $60 / 2.2 \approx 27.3 \mathrm{kV} / \mathrm{cm}$.

The results of laboratory studies of the physicochemical parameters of milk after CHVIA treatment (see Fig. 9) are given in Table 3. 
From the results given in Table 6 it follows that in CHVIA treated milk there is a peroxidase enzyme, the absence of which is characteristic of baked, ultrapasteurized, sterilized milk, that is, milk that was amenable to processing at high temperatures (greater than $100{ }^{\circ} \mathrm{C}$ ). However, in CHVIA treated milk, no enzyme phosphatase was detected, the absence of which is characteristic of pasteurized milk. In addition, from the data of Table 6 it follows that the amount of vitamin $\mathrm{C}$ which is very sensitive to different treatments, after CHVIA treatment has remained at the level meeting the requirements of normative documentation (ND), that is, CHVIA treatment is soft processing. All analyzes (microbiological and sanitary-hygienic) of treated and control samples of watercontaining foods and water were conducted by specialists of the public utility «Sanepidservice» (public unity «SES», the Kharkiv city). This enterprise is accredited by the National Agency of Ukraine for Accreditation (Accreditation Certificate No. 2H1207 of 25.02.2015).

Energy efficiency of high-voltage prototype of CHVIA installation. Energy efficiency is determined by two components: high degree of microbiological (microbial) disinfection of the processed product at a given specific energy input and reduced specific energy consumption in comparison with known methods (for example, thermal sterilization and pasteurization). The first component can be estimated by conducting CHVIA processing and making the corresponding microbiological analyzes of the processed product (water, milk, milk whey). The second component of energy efficiency can be estimated on the basis of what part of the energy consumed from the power supply network by the CHVIA installation was delivered to the $\mathrm{WCH}$ and there it was dissipated leading to the required degree of inactivation of microorganisms in the water. Since in all elements of the CHVIA installation, including in high-voltage capacitors, a transformer and dischargers, not more than 0.1 total energy consumed from the network dissipates in total, efficiency of the installation can be estimated as 0.9 , or $90 \%$ [4-6]. It is more difficult to estimate how much energy is dissipated in the WCH. We do this with the help of oscillograms of voltage pulses on the $\mathrm{WCH}$ with the treated product. A typical oscillogram of the voltage pulse on a chamber with water being treated is shown in Fig. 10.

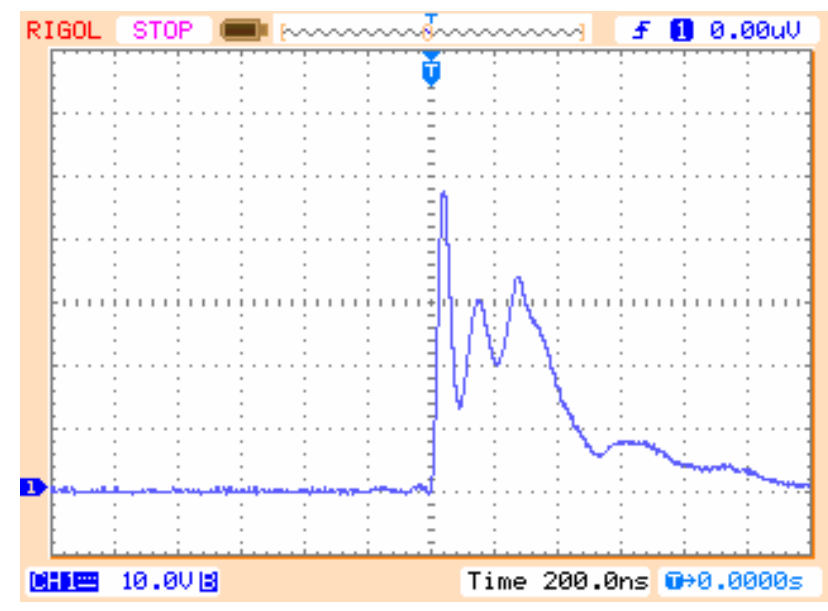

Fig. 10. Typical voltage pulse oscillogram on a working chamber with treated water
The three peaks (maximums), as mentioned above, on the oscillogram correspond to the processes of discharge of three capacitors $(C 1, C 2, C 3)$ on the load the working chamber, in this case filled with water (see Fig. 1). The first (largest) peak after the pulse front is the maximum voltage on the $\mathrm{WCH}$ due to the energy input to the chamber from the most low-inductive discharge circuit with the capacitive storage $C 3$. The second peak corresponds to the process of connecting and discharging capacitor $\mathrm{C} 2$ on the $\mathrm{WCH}$. The third peak corresponds to the process of connecting to the discharge on the $\mathrm{WCH}$ of capacitance $C 1$, more remote from the $\mathrm{WCH}$ and having the greatest inductance.

Energy which is released in the $\mathrm{WCH}$ during processing can be estimated by the formula

$$
E=n T \int i u d t=n T i_{a v} u_{a v} t
$$

where $i$ is the current as a temporal function, $u$ is the voltage as a temporal function, $i_{a v}$ is the averaged current, $u_{a v}$ is the averaged voltage, $t$ is the duration of one pulse at half-height - the length of time during which the energy of the pulse is released in the $\mathrm{WCH}, n$ is the pulse repetition rate, $T$ is the treatment duration.

We suppose that water in the $\mathrm{WCH}$ is a purely resistive load. The pulse duration is determined from the oscillograms.

According to the voltage oscillogram, it is possible to find the active resistance $R_{w c h}$ of water in the chamber, knowing the value of the high-voltage capacitance $C_{h v}$ in which energy is accumulated before after transformation in the transformer ИОМ 100/100 [7]

$$
(t / 0.7)=R_{w c h} \cdot C_{h v}
$$

where $t$ is the pulse duration at half-height, and $t / 0.7$ is the pulse duration before the measured value decreases from the amplitude value in $e \approx 2.71828$ time.

For our installation $C_{h v} \approx 10^{-8} \mathrm{~F}, t \approx 380 \mathrm{~ns}$ (see oscillogram in Fig. 10). Thus

$$
R_{w c h}=(t / 0.7) / C_{h v}=\left(3.8 \cdot 10^{-7} / 0.7\right) / 10^{-8} \approx 54.3 \Omega \text {. }
$$

Taking into account that $u_{a v} \approx 40 \mathrm{kV}, i_{a v}=u_{a v} / R_{w c h}=$ $=40000 \mathrm{~V} / 54.3 \Omega \approx 736.65 \mathrm{~A}$. From here it follows that at $n=400$ pulses $/ \mathrm{s}, T=10 \mathrm{~s}, t=3.8 \cdot 10^{-7} \mathrm{~s}$, the energy $E_{w c h}$ dissipated in the chamber is $E_{w c h}=n T i_{a v} u_{a v} t=400$ pulses $/ \mathrm{s} \times$ $\times 10 \mathrm{~s} \times 736.65 \mathrm{~A} \times 40000 \mathrm{~V} \times 3.8 \times 10^{-7} \mathrm{~s}=16 \times 736.65 \times$ $\times 3.8 \approx 44.8 \mathrm{~kJ}$.

Here, the averaged power $P$ consumed in the $\mathrm{WCH}$ with water approximately equals $P=E_{w c h} / T=44.8 \mathrm{~kJ} / 10 \mathrm{~s} \approx$ $\approx 4.5 \mathrm{~kW}$.

The energy $E_{1 C 1}$ initially stored in the high-voltage discharge circuit in the capacitor $C 1$ before each discharge can be estimated by the formula

$$
E_{1 C 1}=C 1 \cdot u_{C 1}{ }^{2} / 2 \approx 10^{-8} \cdot\left(50 \cdot 10^{3}\right)^{2} / 2=12.5 \mathrm{~J} \text {. }
$$

We estimate the total energy $E_{C 1}$ accumulated in $C 1$ during time $T$

$$
\begin{gathered}
E_{C 1}=n T E_{1 C 1}=400 \text { pulses } / \mathrm{s} \times 10 \mathrm{~s} \times 12.5 \mathrm{~J}= \\
=50000 \mathrm{~J}=50 \mathrm{~kJ} . \\
E / E_{C 1} \approx 44.8 / 50=0.896 .
\end{gathered}
$$

The resistivity of the water in $\mathrm{WCH}$ can be estimated by the formula

$$
\rho=R_{W C H} \times S / l,
$$


where $S$ is the cross-sectional area of $\mathrm{WCH}$ with the liquid to be treated relative to the current flow direction, $l$ is the length of the interelectrode gap in the $\mathrm{WCH}$ i.e. its (working chamber's) height.

At $S=3.14 \cdot 4.75^{2} \cdot 10^{-4}=7.1 \cdot 10^{-3} \mathrm{~m}^{2}, l=1.5 \cdot 10^{-2} \mathrm{~m}$ :

$\rho=54.3 \Omega \times 7.1 \times 10^{-3} \mathrm{~m}^{2} / 1.5 \cdot 10^{-2} \mathrm{~m}=25.7 \Omega \cdot \mathrm{m}$.

We estimate the heating $\Delta t$ of water in a non-current (stationary) $\mathrm{WCH}$ for $T=10 \mathrm{~s}$ with energy $E \approx 44.8 \mathrm{~kJ}$ dissipated in the chamber. If we assume that half of this energy was used to heating the water, and the other half to heating the metal electrodes - the covers of the $\mathrm{WCH}$ and its insulating (fluoroplastic) housing, then

$$
E=2 \cdot c \cdot V \cdot \gamma \cdot \Delta t \text {, i.e. } \Delta t=0.5 \cdot E /(c \cdot V \cdot \gamma),
$$

where $c=4200 \mathrm{~J} /(\mathrm{kg} \cdot \mathrm{K})$ is the specific heat of water, $V$ is the water volume in the $\mathrm{WCH}, \gamma=10^{3} \mathrm{~kg} / \mathrm{m}^{3}$ is the density of water.

$$
\begin{gathered}
V=S \cdot l=7.1 \cdot 10^{-3} \mathrm{~m}^{2} \cdot 1.5 \cdot 10^{-2} \mathrm{~m} \approx 10^{-4} \mathrm{~m}^{3} . \\
\text { So: } \\
\qquad t=0.5 \cdot 44.8 \cdot 10^{3} \mathrm{~J} /(4200 \mathrm{~J} /(\mathrm{kg} \cdot \mathrm{K}) \times \\
\left.\quad \times 10^{-4} \mathrm{~m}^{3} \cdot 10^{3} \mathrm{~kg} / \mathrm{m}^{3}\right)=53.3 \mathrm{~K} .
\end{gathered}
$$

The obtained calculated result is in good agreement with the experimental result on heating water in a given WCH under CHVIA treatment. The measurements were carried out with a M890G tester using a thermocouple. The measured temperature drop from the initial (start) $t_{\text {start }}$ to the final $t_{\text {final }}$ was $\Delta t_{\text {exp }}=t_{\text {final }}-t_{\text {start }} \approx 74-20=54 \mathrm{~K}$. Hence the conclusion follows that practically all the electromagnetic energy reaching the $\mathrm{WCH}$ is released in it in the form of heat. This is of fundamental importance, since both electromagnetic factors (electric and magnetic field strength, voltage and current in the $\mathrm{WCH}$ ) and thermal energy are synergistically directed (unidirectional) factors. This unidirectional effect leads to an increase in the degree of inactivation of microorganisms in the flowable liquid products processed in the WCH. At the same time, all energy supplied to the $\mathrm{WCH}$ is used for its intended purpose - microbiological disinfection of the product processed in the chamber. If we now assume that all the heat released in the chamber is transferred through a heat exchanger to an unprocessed product that has not yet passed through the $\mathrm{WCH}$, then the efficiency $\eta_{e}$ for the given technological process $\eta_{e} \approx 85-99.5 \%$.

An important indicator is also the specific energy consumption of $E_{s p}$, that is, the amount of energy expended for processing a unit (for example, units of volume or mass) of the product. At CHVIA processing in industrial flowing option, when rational heat exchange is involved, this is the amount of electromagnetic energy $E_{\text {flow }}$ introduced into the WCH which in the chamber passes into thermal energy. Here, the product heating $\Delta t_{\text {flow }}$ is guaranteed in the flow mode, while it flows through the $\mathrm{WCH}$, by several $\mathrm{K}$ (for example, by $5 \mathrm{~K}$ ) and the transition from the subcritical temperature to the supercritical temperature of the product which ensures irreversible inactivation of microorganisms under the action of high external pulsed electric field.

Estimation of $E_{\text {flow }}$ and $E_{s p}$

$$
\begin{aligned}
E_{\text {flow }} \approx c \cdot V \cdot \gamma \cdot \Delta t_{\text {flow }}= & 4200 \mathrm{~J} /(\mathrm{kg} \cdot \mathrm{K}) \times 10^{-4} \mathrm{~m}^{3} \times 10^{3} \mathrm{~kg} / \mathrm{m}^{3} \times \\
& \times 5 \mathrm{~K}=2100 \mathrm{~J} ;
\end{aligned}
$$

$$
\begin{gathered}
E_{s p}=E_{\text {flow }} / V=c \cdot \gamma \cdot \Delta t_{\text {flow }}=2100 \mathrm{~J} / 10^{-4} \mathrm{~m}^{3}=2.1 \cdot 10^{7} \mathrm{~J} / \mathrm{m}^{3}= \\
=2.1 \cdot 10^{4} \mathrm{~kJ} / \mathrm{m}^{3}=(21000 / 3600) \mathrm{kW} \cdot \mathrm{h} / \mathrm{m}^{3}= \\
=5.83 \mathrm{~kW} \cdot \mathrm{h} / \mathrm{m}^{3}
\end{gathered}
$$

Thus, the estimated value of the specific energy consumption in the flowing mode at CHVIA treatment of products is $E_{s p}=5.83 \mathrm{kWh} / \mathrm{m}^{3}$. AT the traditional scheme of microbiological milk disinfection (with the help of heat treatment - pasteurization), the specific energy consumption is more, at least 4 times $[1,2]$.

\section{Conclusions.}

1. Rational modes of operation of CHVIA installation for the tested working chambers take place at amplitudes of pulsed electric field strength $E \approx 30 \mathrm{kV} / \mathrm{cm}$ in the liquid in the working chamber and at the treatment duration of $20 \mathrm{~s}$ with high-voltage pulses of duration 300-1200 ns at pulse repetition rate $n \approx 400$ pulses/s.

2. At rational modes in the treated water, milk whey and milk, the demonstrative E.coli bacteria are completely and irreversibly inactivated. In this case, the enzyme peroxidase in milk is preserved. Consequently, the tested rational mode of disinfecting milk treatment is milder than the mode of thermal sterilization, and approximately corresponds to pasteurization.

3. The amount of vitamin $\mathrm{C}$, highly sensitive to various treatments, after treating milk in rational modes is maintained at a level that meets the requirements of regulatory documentation, that is, CHVIA treatment is a soft treatment that preserves the biological and nutritional value of the products.

4. Estimated value of specific energy consumption in flowing mode AT CHVIA treatment of products is $E_{s p} \approx 6 \mathrm{kWh} / \mathrm{m}^{3}$, which is about 4 times less than at traditional heat treatment. At the same time, the energy efficiency of the proposed complex of high-voltage pulse actions is 4 times higher compared with pasteurization.

5. The results of the performed investigations open the prospect of the industrial application of a complex of highvoltage pulse actions for the disinfecting treatment of water-containing food products.

\section{REFERENCES}

1. Minuhin L.A., Gaffner V.V., Menshenin G.A. Study the possibility of reducing energy consumption during the pasteurization of milk on small enterprises. Agrarnoe obrazovanie i nauka, 2016, no.3. (Rus).

2. Solovyov S.V. Povyshenie effektivnosti protsessa teplovoy obrabotki moloka putem obosnovaniya konstruktivnykh $i$ tekhnologicheskikh parametrov nagrevatelya. Diss. cand. techn. nauk [Improving the efficiency of the process of milk thermal processing by justifying the design and technological parameters of the heater. Cand. tech. sci. diss.]. Velikie Luki, Russia, 2016. 155 p. (Rus).

3. Boyko N.I., Tur A.N., Evdoshenko L.S., Zarochentsev A.I. High-voltage pulse generator with an average power of up to 50 $\mathrm{kW}$ for treatment of food products. Instruments and experimental technique, 1998, no.2, pp. 120-126. (Rus).

4. Kuchinskiy G.S. Vysokovoltnye impulsnye kondensatory. [High-voltage pulse capacitors]. Leningrad, Energiya Publ., 1973. 176 p. (Rus). 
5. Losses and efficiency in transformers. Available at: M.I. Boyko ${ }^{1}$, Doctor of Technical Sciences, Professor, www.ets.ifmo.ru/usolzev/SEITEN/u2/tr/1 9.htm (accessed 15 A.V. Makogon ${ }^{1}$,

May 2017). (Rus)

6. Mesiats G.A. Impul'snaia energetika i elektronika [Pulsed power and electronics]. Moscow, Nauka Publ., 2004. 704 p. (Rus).

7. Bogatenkov I.M., Imanov G.M., Kizevetter V.E. Tekhnika vysokikh napriazhenii: Uchebnoe posobie dlya vuzov [High voltage techniques]. Saint Petersburg, PEIPK Publ., 1998. 700 p. (Rus).

A.I. Marynin ${ }^{2}$, Candidate of Technical Sciences, Associate Professor,

${ }^{1}$ National Technical University «Kharkiv Polytechnic Institute», 2, Kyrpychova Str., Kharkiv, 61002, Ukraine, phone +380 57 7076245,

e-mail: qnaboyg@gmail.com

${ }^{2}$ National University of Food Technologies,

68, Volodymyrska Str., Kyiv, 01601, Ukraine, e-mail: andrii_marynin@ukr.net

Received 13.03.2018

How to cite this article:

Boyko M.I., Makogon A.V., Marynin A.I. Energy efficiency of the disinfection treatment of liquid foodstuffs by highvoltage pulse effects. Electrical engineering \& electromechanics, 2018, no.3, pp. 53-60. doi: 10.20998/2074272X.2018.3.07. 